\title{
PARTICIPATION, RESPONSIVENESS, AND THE CONSULTATIVE PROCESS: AN ESSAY FOR LON FULLER
}

\author{
Melvin Aron Eisenberg*
}

\begin{abstract}
In this essay, Professor Eisenberg identifies three norms of the adjudicative process put forth by Professor Fuller in The Forms and Limits of Adjudication - attention by the decisionmaker, explanation of the decision, and responsiveness of the decision to the parties' proofs and arguments. Professor Eisenberg argues that there is a form of social ordering which, like adjudication, is characterized by assutred participation, but which does not require that the decision be responsive to the parties' proofs and arguments. He explores some of the current and potential applications of this form of social ordering, which he terms the Consultative Process. He goes on to conclude that even in adjudication the norm of responsiveness to the proofs and arguments of the parties may vary according to the nature of the problem presented and the various interests to be accommodated in the solution of that problem.
\end{abstract}

\begin{abstract}
T ON FULLER was a great figure in the law. I was fortunate to have known him personally over the years in three capacities - as a teacher, as a colleague during a visiting year at Harvard, and as a coauthor. Each was a treasured association. I continue to know him intellectually through the gift of his work. His thought in the areas of contracts and the legal process has shaped my thought immeasurably. In substance and in style his work fused in an often breathtaking way three elements that are usually incommensurate - profundity, elegance, and a sure touch for the colloquial and the everyday. Although I differ with his work in some particulars, I like to think that I follow the direction of his thought in all the fundamentals.
\end{abstract}

One of the major themes in Lon Fuller's work is the continuity between official and unofficial forms of social ordering - a theme illustrated by the opening passage of The Forms and Limits of Adjudication, which juxtaposes adjudication by courts, by parents, and by the Congregation of Rites. ${ }^{1}$ A closely related theme is

\footnotetext{
* Professor of Law, University of California, Berkeley. A.B., Columbia, I956; LL.B., Harvard, I959.

I am indebted to Phillipe Nonet, Phil Selznick, Martin Shapiro, Preble Stolz, and Jan Vetter for their extremely valuable criticisms and suggestions in connection with earlier drafts, and to David Bryson, Howard Latin, Ken Phillips, and John Sodergren for their important help on particular issues.

${ }^{1}$ Fuller, The Forms and Limits of Adjudication, 92 HARv. L. REv. 353, 353-54 (1978) [hereinafter cited as Forms and Limits].
} 
an emphasis on the extent to which ordering is not merely a top-down phenomenon, but tends in all its forms to involve participation by persons who will be affected by decisions. In such essays as Human Interaction and the Law, ${ }^{2}$ Fuller addressed forms of ordering that involve participation which is not "institutionally defined and assured," ${ }^{3}$ such as the interaction among individuals that gives rise to customary law, the interaction between lawmaker and citizenry, and the interaction between manager and those who are managed. ${ }^{4}$ In contrast, in Forms and Limits Fuller addressed ordering processes involving participation that is institutionally guaranteed. Two such processes are taken up largely for comparative purposes: contract, in which participation takes the form of negotiation, and election, in which participation takes the form of voting. The central focus is on the process of adjudication, and the central proposition - which I shall refer to as the Participation Thesis - is that the distinguishing characteristic of that process "lies in the fact that it confers on the affected party a peculiar form of participation in the decision, that of presenting proofs and reasoned arguments for a decision in his favor." 5 Fuller went on to argue that the norms of the adjudicative process can be derived from that Thesis, and then explored the limits of adjudication as an ordering process, particularly as to the resolution of "polycentric" problems. Part I of this essay will consider some implications of the Participation Thesis in more detail, will identify and examine another important form of social ordering that involves assured participation, and will compare that form with adjudication. Part II will explore the limits of adjudication. Part III will examine the continued relevance of Fuller's model of adjudication in light of developments in litigation since Forms and Limits was written.

\section{A. Attention, Explanation, and Responsiveness}

I shall focus on three norms of the adjudicative process that emerge from Forms and limits.

(i) The adjudicator should attend to what the parties have to say.

${ }^{2}$ Fuller, Human Interaction and the Law, I4 AM. J. JURIS. I (Ig69).

3 The phrase is from Forms and Limits, supra note I, at 366.

${ }^{4}$ See also L. Fuller \& M. Eisenberg, Basic Contract Law 89-1o3 (3d ed. I972) ; Hart, The Relations Between State and Federal Law; 54 CoLuM. L. REv. 489,489 (1954) ("Historically, the law begins and has to begin at the grass roots. Currently and continuously in the continuous current of time the same thing is true.").

${ }^{5}$ Forms and Limits, supra note I, at 364 . 
(ii) The adjudicator should explain his decision in a manner that provides a substantive reply to what the parties have to say.

(iii) The decision should be strongly responsive to the parties' proofs and arguments in the sense that it should proceed from and be congruent with those proofs and arguments.

One function of adjudication is the settlement of past disputes. Frequently the adjudicator assumes a second function of making rules to govern future conduct. ${ }^{6}$ The norms of attention, explanation, and strong responsiveness differ considerably in the extent to which they promote these two functions and follow from the Participation Thesis.

Attention is critical to meaningful performance of the disputesettlement function and to meaningful participation, and is not inconsistent with rulemaking. The norm of attention is therefore applicable in all cases.

Explanation is normally a condition to performance of the rulemaking function, since rules ordinarily cannot emerge from an outcome unless the reasons for that outcome are given. Explanation may advance the dispute-settlement function by helping to satisfy the loser that the decision is not arbitrary. It may also advance participation by giving assurance that the adjudicator has in fact attended. ${ }^{7}$ Explanation is not critical, however, to either dispute settlement or meaningful participation. The norm of explanation may therefore occasionally be disregarded, particularly where the adjudicator does not have a rulemaking function, as is often the case in commercial arbitration. ${ }^{8}$

The norm of strong responsiveness is more complex. Fuller argued that the party's right to present proofs and reasoned arguments and the decisionmaker's obligation to attend to those proofs and arguments distinguishes adjudication from all other forms of social ordering, including those (such as contract and election) which involve some type of assured participation. ${ }^{\circ}$ Taken at face value this proposition seems incorrect, since, as will be shown below, there is an ordering process other than adjudication that "confers on the affected party [the opportunity of] ... presenting proofs and reasoned arguments for a decision in his

\footnotetext{
"Throughout this essay, I shall use the term "rules" to include principles and standards as well. See generally H. HART \& A. SAcrs, The Legar Process I54-60 (tent. ed. I958).

${ }^{7}$ See Forms and Limits, supra note $\mathrm{x}$, at 388.

${ }^{8}$ See id. at 389-90; M. Domke, The Law and Practice of Commerctad ARBITRATION \& 29.06 (Ig68).

${ }^{\circ}$ See Forms and Limits, supra note $\mathrm{I}$, at 364,366 .
} 
favor." What distinguishes adjudication from other forms of social ordering is not simply that the parties have the right to present proofs and reasoned argument to which the decisionmaker must attend, but that the decision ought to proceed from and be congruent with those proofs and arguments. To put this differently, strong responsiveness does not follow from the Participation Thesis, but is an independent norm which both helps define adjudication and gives a special meaning to participation through proofs and arguments. To this extent, strong responsiveness is a critical characteristic of the adjudicative process. Strong responsiveness is also related to the dispute-settlement function, insofar as the parties contemplate that the court will settle their dispute on the basis of the issues as the parties see them.

There is, however, a serious potential conflict between strong responsiveness and the rulemaking function. The rules that an adjudicator lays down must anticipate applications to persons far removed from the current disputants, and must be responsive to those other persons' needs as well. Insofar as the issues framed by the parties do not adequately address those long term needs, the norm of strong responsiveness may conflict with the adjudicator's rulemaking function - for example, where the parties argue the case on the basis of an existing rule that the adjudicator believes should no longer be followed. ${ }^{10}$ The force of this norm may therefore vary according to the nature of the inquiry and the quality of the parties' participation. As to the establishment of adjudicative facts (facts relevant in deciding whether a given rule is applicable), in many instances, and most prominently in classical common lawi litigation, an adjudicator is generally bound by the parties' proofs, and cannot rely either on his own prior knowledge or on independent inquiry. In contrast, as to both reasoned argument and the establishment of legislative facts (facts relevant in deciding what rules should be recognized as authoritative) ${ }^{11}$ the norm of strong responsiveness is often more of an ideal than an obligation. Nevertheless, "[i]f the ideal of a perfect congruence between the arbiter's view of the issues and that of the parties is unattainable, this is no excuse for a failure to work toward an achievement of the

\footnotetext{
${ }^{10}$ See, e.g., MacPherson v. Buick Motor Co., 217 N.Y. 382, III N.E. I050 (Igx6).

12 In my definition of adjudicative facts I have followed H. HART \& A. SAcks, supra note 6, at 384. For different formulations, see FED. R. Evm. 20r, Advisory Committee Commentary; K. Davis, I Administrative Law Treatise $\S 7.02$, at 413 (1958). See also Robinson, The Making of Administrative Policy: Another Look at Rulemaking and Adjudication and Administrative Procedure Reform, II8 U. PA. L. REV. 485, 52I-23 (I970).
} 
closest approximation of it." 12 So, for example, it is certainly deemed undesirable, although perhaps not impermissible, for a court in determining legislative facts to rely on empirical studies not considered by either party. If the court goes a step further, and privately consults expert parties for help in establishing legislative facts, it probably would be subject to reversal. ${ }^{13}$ In Goldberg v. Kelly, ${ }^{14}$ which held that benefits under Aid to Families with Dependent Children could not be cut off without an opportunity for a prior hearing, the Supreme Court went so far as to say that due process required that the conclusion as to eligibility must rest solely on the legal rules adduced at the hearing. ${ }^{10}$ This prescription may seem excessive, but it is clear that, at a minimum, it would be considered bad practice for an adjudicator consistently to reach decisions on the basis of a rule not adduced by the parties, and worse to reach decisions on the basis of rules the parties have not addressed.

\section{B. The Consultative Process}

This Section will develop a form of social ordering that I shall call the consultative process. As in adjudication, the consultative process involves assured participation that takes the form of affording affected parties the right to present reasoned argument and, to varying degrees, proofs for a decision in their favor. As in adjudication, the decisionmaker in the consultative process is always obliged to attend to these arguments and proofs before he makes his decision, and is normally obliged to explain his decision. The consultative process is distinguished from adjudication by the fact that the norm of strong responsiveness is inapplicable - that is, the decision need not proceed from or be congruent with the parties' proofs and arguments. Instead, the decisionmaker may base his decision solely on evidence he has himself collected, on his own experience, on his institutional preferences, and on rules neither adduced nor addressed by the parties.

Like the adjudicative process, the consultative process may take more than one form. In the purest version of the process, if the affected parties have been given notice of the proposal and an opportunity to present their views, and the decisionmaker has considered those views in good faith, no more is required except

\footnotetext{
${ }^{12}$ Forms and Limits, supra note $\mathrm{I}$, at 388 .

${ }^{13}$ See ABA Code of Judicinl Conduct Canon 3 (A) (4) (1977).

14397 U.S. 254 (1970).

15 Id. at $27 \mathrm{I}$; cf. Morgan v. United States, 304 U.S. I, I8 (1938) ("The right to a hearing embraces ... a reasonable opportunity to know the claims of the opposing party and to meet them. The right to submit argument implies that opportunity; otherwise the right may be but a barren one.").
} 
that the decision not be made for an improper reason and that it be explained. ${ }^{16}$ In major variants, the process can be coupled either with judicial review of the decision on the basis of the facts and rules properly considered by the decisionmaker, ${ }^{17}$ or with an adjudicative hearing afforded only after the decision has been given provisional effect. ${ }^{18}$

A leading illustration of the consultative process is provided by the Administrative Procedure Act. Under section 553 of that Act: ${ }^{10}$

(b) General notice of proposed rule making shall be published in the Federal Register .... The notice shall include ...

(3) either the terms or substance of the proposed rule or a description of the subjects and issues involved.

(c) After notice required by this section, the agency shall give interested persons an opportunity to participate in the rulemaking through submission of written data, views, or arguments with or without opportunity for oral presentation. After consideration of the relevant matter presented, the agency shall incorporate in the rules adopted a concise general statement of their basis and purpose. ${ }^{20}$

Where section 553 applies, an agency proposing a new rule must give affected parties an opportunity to present proof (in the form of "written data") and reasoned arguments and is obliged both to attend to those proofs and arguments and to explain its action. However, the rules it issues need not proceed from or be congruent with the participants' proofs and arguments. Indeed, the rules as issued may accommodate none of these proofs and arguments, provided they have a factual basis and fall within the limits of rationality. ${ }^{21}$

Other important illustrations can be found in various rules governing administrative decisions as to the rights and obligations of particular individuals. For example, HUD regulations provide

${ }^{10} \mathrm{Cf}$. Rabin, Job Security and Due Process: Monitoring Administrative Discretion Through a Reasons Requirement, 44 U. CHI. L. REv. 60, 77 (1976) ("Fundamental to the concept of due process is the right to a reasoned explanation of government conduct that is contrary to the expectations the government has created ....".).

${ }^{17}$ See pp. 418-Ig infra.

${ }^{18}$ See p. $42 \mathrm{r}$ \& note 49 infra.

${ }^{19} 5$ U.S.C. $\& 553$ (I976).

20.Id.

${ }^{21}$ See, e.g., Moss v. FPC, 502 F.2d 64I, 645 (D.C. Cir. 1974); Angel v. Butz, 487 F.2d 260, 263 (roth Cir. x973), cert. denied, 4I7 U.S. 967 (I974); General Tel. Co. v. United States, 449 F.2d 846, 86I-62 (5th Cir. I97I); Administrative Conference Recommendation 74-4, in 3 ADMTNISTRATIVE CoNFERENCE of THE UNITED STATES, RECOMMENDATIONS AND REPORTS 50 (1973-I974). 
that a Public Housing Agency which proposes to modernize a low-income housing project with HUD funds must "notify the residents of the project . . . of the proposed modernization program, afford residents a reasonable opportunity to present their views on the proposed program and alternatives to it, and give full and serious consideration to resident recommendations." 22 The Housing and Community Development Amendments of 1978 provide that HUD's secretary

shall assure that -

(I) where the Secretary's written approval is required with respect to [the action of an owner of a subsidized multifamily dwelling] and the Secretary deems it appropriate, tenants have adequate notice of, reasonable access to relevant information about, and an opportunity to comment on such actions . . . and that such comments are taken into consideration by the Secretary. ${ }^{23}$

HEW regulations provide that after notification of a proposed termination of disability insurance benefits under the social security laws, the beneficiary must be given opportunity to respond in writing and to submit evidence on his behalf. An adverse decision entitles the beneficiary to an evidentiary hearing, but the agency action stands pending that hearing. ${ }^{24}$

${ }^{22} 24$ C.F.R. \& 868.5 (I977). The regulation goes on to provide that "the PHA shall provide HUD with an evaluation of resident recommendations, indicating the reasons for PHA acceptance or rejection, consistent with . . . [its] own determination of efficiency, economy, and need."

${ }^{23}$ Housing and Community Development Amendments of 1978, Pub. L. No. 95-557, \& 202 (b), 92 Stat. 2088.

For other examples in the tenants' rights area, see 24 C.F.R. §§ 40x.x-.6 ( 1978$)$; id. $\$ \S 86 \mathrm{I} .40 \mathrm{I}-.404$ (1977) (tenants of federally subsidized private housing projects and federally assisted local housing authorities must be given notice of proposed rent increases and an opportunity to make written comments); Caramico v. Secretary of Dep't of Hous. \& Urban Dev., 509 F.2d 694 (2d Cir. 1974) (FHA, in determining whether to waive its right to require an insured mortgagee to deliver premises in an unoccupied state, must afford the tenants an opportunity to submit argument and evidence that they wish to have taken into account). The cited regulations codify the holdings in Geneva Towers Tenants Organization v. Federated Mortgage Investors, 504 F.2d 483 (gth Cir. I974); Thompson v. Washington, 497 F.2d 626 (D.C. Cir. x973); Marshall v. Lynn, 497 F.2d 643 (D.C. Cir. I973), cert. denied, 4I9 U.S. 970 (1974); and Burr v. New Rochelle Mun. Hous. Auth., 479 F.2d 1165 (2d Cir. 1973).

2420 C.F.R. \$\$ 404.905, .907, .914, .917 (1978); see Mathews v. Eldridge, 424 U.S. $319,335-39$ (1976). For examples in other areas, see Goss v. Lopez, 419 U.S. 565 (I975); H. WAdE, ADMINISTRATTVE LAW 393, 399, 42 I-88 (4th ed. I977) (English practices).

A rather different kind of illustration can be found in the field of labor relations. Under $\$ \S 8(a)(5)$ and 8 (d) of the National Labor Relations Act, 29 U.S.C. \& I58(a) (5), (d) (1976), if a union has been elected as collective bargaining agent, the employer is obliged to negotiate in good faith. Fuller pointed out that " $[w]$ hen I am entering a contract with another person I may present proofs 
What is the purpose of erecting a process that assures the right to present proof and reasoned argument, if the decision need not proceed from and be congruent with that proof and argument? Essentially, the employment of such a process rests on four premises: (i) Where a decision will have a serious impact on a discrete set of persons, preservation of individual dignity points to the desirability of an ordering process in which those persons will be able to express their view of the matter to the decisionmaker before the decision is made. ${ }^{25}$ (ii) Requiring the decisionmaker to attend to the parties' proofs and arguments serves the societal interest of assuring that decisions are well informed. (iii) Requiring decisions to proceed from and be congruent with the parties' proofs and arguments is often inappropriate or infeasible, either because of the nature of the subject-matter or the nature of the setting. (iv) Decisionmakers will normally accommodate their decisions to convincing proofs and arguments even though not obliged to do so, and are more likely to make such accommodation in shaping decisions than in unmaking or revising them.

For the consultative process to work effectively, it must be characterized by openmindedness on the part of the decisionmaker and restraint on the part of a reviewing court. It is a process based on trust - trust that either the decisionmaker will act fairly if well informed, or that persistent substantive unfairness can and will be corrected by processes other than substantive judicial review, such as public criticism or removal from office.

and arguments to him, but there is generally no formal assurance that I will be given this opportunity or that he will listen to my arguments if I make them," and added that "[p]erhaps the only exception to this generalization lies in the somewhat anomalous legal obligation 'to bargain in good faith' in labor relations." Forms and Limits, supra note $I$, at 366 . As $\S 8(d), 29$ U.S.C. $\S ~ I 58(d)$ makes clear, however, this obligation does not impose upon the employer a duty to agree: the employer remains the decisionmaker, and if negotiation reaches an impasse it is legally entitled to make decisions unilaterally. On analysis, then, mandatory bargaining in good faith can be viewed as simply a form of consultative process: what is required is that the employer at a minimum attend to the union's proofs (in the form of data) and arguments. Presumably, if the employer does not accept the validity of the proofs or the force of the arguments it is also obliged to explain why. But having attended to the union's proofs and arguments in good faith, the employer is free to make a decision which in no way accommodates those proofs and arguments. See, e.g., Chevron Oil Co. v. NLRB, 442 F.2d 1067, I072-73 (5th Cir. I97I); NLRB v. Cummer-Graham Co., 279 F.2d 757 (5th Cir. rg60). The employer's decisionmaking power and decisionmaking process are of course subject to the check of collective action. However, that would be true even if the statute did not impose the duty to negotiate in good faith. The statute therefore operates in just those cases where the union's economic power might not.

${ }^{25}$ See L. Tribe, American Constitutional Law § IO-7 (I978). 


\section{Two Applications}

I. Administrative Rulemaking Under the APA.-Section 706 of the Administrative Procedure Act ${ }^{26}$ provides that where administrative rulemaking is required to be on the basis of a record, the test on judicial review is whether the rule is supported by substantial evidence. Rulemaking on the record, however, is a relatively exceptional case. More typically, administrative rulemaking proceeds under the notice-and-comment procedures of APA section 553, and in such cases the rule may be set aside only if it is found to be "arbitrary, capricious, an abuse of discretion, or otherwise not in accordance with law." ${ }^{27}$ Two competing models of review can be presented under this standard, which I shall call Consultative I and Consultative II. Under Consultative I the court reviews not only whether the agency considered relevant data and criteria, but whether it evaluated the data soundly and gave appropriate weight to competing criteria. Under'this model, if the agency in making its rule gave a certain criterion a weight of Ioo, and the court believes that the criterion, while relevant, deserves a weight of only $I$, the rule would not be upheld. ${ }^{28}$ In contrast, under Consultative II the court reviews only to determine whether the rulemaker has given actual, good faith consideration to all relevant factors. If the agency has "in fact given serious attention to a factor, the weight which [it] assigns to it in [its] final judgments is of virtually no concern to the reviewing court. ... [O]nce the court is satisfied that the administrator did touch all the bases, absent obvious irrationality, there is little more a court can accomplish." ${ }^{20}$

Whether a model of review corresponding to Consultative I better interprets the meaning of the arbitrary-or-capricious standard than one corresponding to Consultative II is a subject of lively debate. ${ }^{30}$ On the face of the APA either interpretation seems permissible, ${ }^{31}$ and as a practical matter it seems likely that the two models are concurrently employed, each for certain kinds of agencies or certain kinds of rules. Assuming that such a bifurcated approach is proper under the statute (an issue beyond the province of this essay), development of the consultative

${ }^{26} 5$ U.S.C. $\$ 706(2)$ (E) (r976).

${ }^{27}$ See id. $\S 706(2)(A)$.

${ }^{28}$ Cf. K. Davis, Admintstrative Law of the Seventies $\S 29.01-5$, at 667 (I976) (criticizing Wright, The Courts and the Rulemaking Process: The Limits of Judicial Review, 59 CORNeLr L. Rev. 375 (1974)).

29 Wright, supra note 28 , at 392-93.

${ }^{30}$ Compare $\mathrm{K}$. Davis, supra note 28 , at 667 , with Wright, supra note 28 . For discussion, see Friendly, "Some Kind of Hearing," I23 U. PA. L. REv. r267, 1305I5 (I975).

${ }^{31}$ But see K. Davis, supra note 28 , at $667-68$. 
process should lead to explicit judicial inquiry into what criteria determine which model should be employed in specific cases.

2. Administrative Decisionmaking and the Due Process Clause. - Under the Constitution no person may be deprived by government of "life, liberty, or property" without due process of law. ${ }^{32}$ What constitutes "liberty" and "property" within the meaning of the due process clause is something of an open question; the compass of the definition has varied over recent years. Under one view, "life, liberty, or property" should be interpreted broadly to include all aspects of an individual's life in society, on the ground that, used in conjunction, "the three terms are generic descriptions for all individual interests." ${ }_{33}$ The Supreme Court, however, has taken a much narrower view, and has explicitly rejected "the notion that any grievous loss visited upon a person by the State is sufficient to invoke the procedural protections of the Due Process Clause." ${ }^{4}$ Thus, in Paul v. Davis ${ }^{35}$ the Court held that the police could distribute a flier identifying a person as an "active shoplifter" without providing the individual any procedural safeguards, because issuing such a flier does not involve a deprivation of liberty or property. Similarly, in Meachum v. Fano ${ }^{30}$ the Court held that a prisoner can be transferred for disciplinary reasons to a substantially less favorable prison without being afforded any procedural safeguards, because such a transfer does not implicate a liberty interest.

There is reason to believe that the Court's relatively narrow reading of what constitutes "life, liberty, or property" reflects a notion that whenever a due process interest is implicated, the state must afford some sort of adjudicative hearing coupled with an opportunity for judicial review on the merits. For example, in Meachum the Court stated:

[T]o hold as we are urged to do that any substantial deprivation imposed by prison authorities triggers the procedural protections of the Due Process Clause would subject to judicial review a wide spectrum of discretionary actions that traditionally have been the business of prison administrators rather than of the federal courts. ...

Holding that arrangements like this are within reach of the procedural protections of the Due Process Clause would place the Clause astride the day-to-day functioning of state prisons and

${ }^{32}$ U.S. ConsT. amend. V; id. amend. XIV, § I.

${ }^{33} \mathrm{~J}$. Nowak, R. Rotunda \& J. Young, Constitutionar Law 478 n.I (I978).

${ }^{34}$ Meachum v. Fano, 427 U.S. 2I5, 224 ( 1976 ) (emphasis in original); Ingraham v. Wright, 430 U.S. 65I, 672 (1977).

${ }^{35} 424$ U.S. 693 (I976).

${ }^{36} 427$ U.S. 215 (I976). 
involve the judiciary in issues and discretionary decisions that are not the business of federal judges. ${ }^{37}$

It seems clear from this passage that in determining whether the interest involved in Meachum constituted "liberty," the Court did not confine itself to an analysis of the interest, but also looked at - and indeed heavily relied upon - the procedural consequences it believed would follow from the definition. It follows that if there are cases in which the consultative process can satisfy the due process clause, the way would be opened for a more expansive definition of "life, liberty, or property," since the elements of that process are relatively modest and the scope of judicial review can be extremely limited. ${ }^{38}$

Over the last ten years, the Supreme Court has made clear that the process which is due depends on the character of the interest infringed. In Goldberg $v$. Kelly ${ }^{30}$ the Court held that the right to receive continued benefits under the federal Aid to Families with Dependent Children program constitutes a "statutory entitlement" and cannot be cut off unless the recipient is afforded a prior "evidentiary" hearing - the elements of which include timely and adequate notice detailing the reasons for the proposed action, an impartial decisionmaker, effective opportunity for the beneficiary to present oral evidence and arguments, the right to confront adverse witnesses, the right to be represented by retained counsel, a decision resting solely on the legal rules and evidence adduced at the hearing, and a statement of reasons for the decision. Such a hearing obviously involves the essential attributes of a judicial - or more accurately, an adversarial - model, although the Court indicated that precise conformity to that model was not required. ${ }^{40}$ In Morrissey $v$. Brewer ${ }^{41}$ the Court held that revocation of parole involves a deprivation of liberty and that the parolee is entitled to a preliminary hearing immediately after the arrest to determine probable cause and to a final hearing before revocation to determine whether revocation is warranted. The Court took the procedural requirements of Goldberg as a starting point, but concluded that a parolee can be denied the right to confront and cross-examine adverse witnesses if the hearing officer finds good cause for not

${ }^{37} I d$. at $225,228-29$ (emphasis in original).

${ }^{38}$ Cf. Rabin, supra note I6 (a comparable analysis arguing that the due process clause requires at least an explanation in certain cases - particularly those involving job security - in which the Court has declined to recognize a property interest).

${ }^{39} 397$ U.S. 254 (1970).

${ }^{40}$ Id. at 266 . For example, a record need not be kept, and, presumably, the rules of evidence can be relaxed. $I d$. at 267 .

${ }^{41} 408$ U.S. $47 \times$ (1972). 
allowing confrontation. ${ }^{42}$ In Wolff $v$. $M c$ Donnell ${ }^{43}$ the Court held that rescinding a prisoner's good-time credit or placing him in solitary constitutes a loss of liberty, and cannot be effected without a prior hearing. The Court took the procedural requirements of Morrissey as a starting point, but concluded that a prisoner can be denied the right to call his own witnesses where prison officials determine it will be unduly hazardous to institutional safety or correctional goals, and that there is normally no right to either retained or appointed counsel. ${ }^{44}$

If, as these cases teach, the process that is due may vary according to the character of the interest infringed, it would follow that there may be some cases in which the process that is due before an interest is infringed is no more but no less than a consultative hearing - that is, a hearing in which the individual is entitled to notice of the action under consideration, a right to give his side, and an explanation of the decision. Such an approach is implicit - indeed, all but explicit-in Mathews $v$. Eldridge ${ }^{45}$ and Goss v. Lopez. ${ }^{46}$ In Matheres v. Eldridge the Court reviewed the procedures for terminating social security disability payments. Under these procedures the beneficiary is entitled to an evidentiary hearing after termination, but before termination has only the right to be notified of the proposed action and an opportunity to review his file, to respond in writing, and to submit additional evidence ${ }^{47}$ - in other words, only the right to a consultative process. The Court upheld these procedures against an attack on due process grounds, stating that "the ordinary principle" is "that something less than an evidentiary hearing is sufficient prior to adverse administrative action," 48 and strongly implying that its approval depended as much on the procedures available before termination as on those available thereafter. ${ }^{49}$

42 Id. at 487,489 .

${ }_{43}^{418}$ U.S. 539 (I974).

${ }^{44}$ The Court in Wolff held that counsel may be required where the inmate is illiterate or the issues are complex. Id. at 570. In Morrissey the Court had not passed upon the right to counsel. In Gagnon v. Scarpelli, 4II U.S. 778, 790-9I (I973), which applied the Morrissey rules to revocation of probation, the Court concluded that counsel ordinarily does not have to be provided if the case is not complex and the probationer appears capable of speaking effectively for himself.

${ }_{45}^{424}$ U.S. 3 I9 (I976).

${ }^{48} 419$ U.S. 565 (I975).

${ }^{47} 424$ U.S. at $337-38$.

${ }^{48}$ Id. at 343 .

${ }^{49}$ Id. at 348-49. Similarly, in Arnett v. Kennedy, 416 U.S. I34, I70-7I (1974), Justice Powell, concurring, concluded that due process was satisfied in the discharge of a federal employee by a combination of the right to present argument to the decisionmaker prior to discharge, and a full evidentiary hearing after the 
In Goss v. Lopez the Court held that a public school student ordinarily can not be put on short term suspension unless he is first given "oral or written notice of the charges against him and, if he denies them, an explanation of the evidence the authorities have and an opportunity to present his side of the story." ${ }^{0}$ "The Court made clear that the procedure it envisioned was the kind of hearing I have labeled consultative.

[I] $t$ would be a strange disciplinary system in an educational institution if no communication was sought by the disciplinarian with the student in an effort to inform him of his dereliction and to let him tell his side of the story in order to make sure that an injustice is not done. . . .

We stop short of construing the Due Process Clause to require, countrywide, that hearings in connection with short suspensions must afford the student the opportunity to cross-examine witnesses supporting the charge, or to call his own witnesses to verify his version of the incident. . . .

On the other hand, requiring effective notice and informal hearing permitting the student to give his version of the events will provide a meaningful hedge against erroneous action. At least the disciplinarian will be alerted to the existence of disputes about facts and arguments about cause and effect. . . .

Requiring that there be at least an informal give-and-take between student and disciplinarian, preferably prior to the suspension, will add little to the factfinding function where the disciplinarian himself has witnessed the conduct forming the basis for the charge. But things are not always as they seem to be, and the student will at least have the opportunity to characterize his conduct and put it in what he deems the proper context..$^{51}$

Requiring some sort of consultative process before a state agency imposes grievous harm will seldom put a strain on institutional resources. In many cases it will probably be found that such a process is already required by the agency's own rules or practices. In Meachum v. Fano itself, each prisoner had been given notice of the allegations against him, was allowed to present evidence on his own behalf prior to the determination, and was given an explanation for the classification board's action - that is, each prisoner was accorded consultative due process. Nor need

discharge. A substantially comparable position was taken by Justice White. Id. at 200-02 (White, J., concurring in part and dissenting in part).

${ }^{50} 4 \mathrm{rg}$ U.S. at $58 \mathrm{r}$.

51 Id. at 580, 583-84; cf. John v. Rees, [r970] I Ch. 345, 402 ("[T]he path of the law is strewn with examples of open and shut cases which, somehow, were not; of unanswerable charges which, in the event, were completely answered; of inexplicable conduct which was fully explained; of fixed and unalterable determinations that, by discussion, suffered a change.") 
such a process put a substantial strain on the courts, if they are willing to apply the model of review embodied in Consultative II. 52 To the extent the Court has held that particular interests were not "life, liberty, or property" because it has associated that characterization with a requirement of an evidentiary hearing and review on the merits, recognition of the consultative process as due process in appropriate cases warrants a second look at the notion that the State can inflict grievous harm on an individual without having afforded him even so minimal a set of rights as notice, attention, and explanation.

\section{II}

Fuller was at least as interested in the limits of adjudication as in its form. In marking out these limits he relied largely on the concept of "polycentricity." Fuller tended, in Forms and Limits and elsewhere, ${ }^{53}$ to define this concept more by example than by explication. A favorite example was a case in which a testatrix named Timken bequeathed a valuable collection of paintings to two museums "in equal shares" and the problem was how to divide the collection. ${ }^{54}$ Another recurring example was the problem of picking players for positions on a football team..$^{\mathbf{5 5}}$ Still a third example, taken up by Fuller in a slightly different context in Irrigation and Tyranny ${ }^{56}$ and again later in Mediation - Its Forms and Functions, ${ }^{57}$ is the problem faced by the watermaster of an irrigation district in allocating scarce water among the district's farmers. Probably the closest approach to an explicit definition in Forms and Limits is that a polycentric problem is one which involves "a situation of interacting points of influence." 58 Thus the Timken problem is polycentric because the two museums cannot simply list all the paintings in order of

${ }^{52}$ Cf. Dunlop v. Bachowski, 42I U.S. 560, 572-73 (I975) (ordinarily, review of a decision by the Secretary of Labor not to seek to set aside a contested union election 'should be confined to examination of the 'reasons' statement, and the determination whether the statement, without more, evinces that the Secretary's decision is so irrational as to constitute the decision arbitrary and capricious.").

${ }^{53}$ See, e.g., Fuller, Adjudication and the Rule of Law, I960 Proc. AM. Soc'y of INT'L L. I, 3-5 [hereinafter cited as Adjudication and the Rule of Law]; Fuller, Collective Bargaining and the Arbitrator, 1963 WIs. L. REv. 3, 30-39 [hereinafter cited as Collective Bargaining].

${ }^{54}$ Forms and Limits, supra note $\mathrm{I}$, at 394 ; Adjudication and the Rule of Law, supra note 53, at 3 ; Collective Bargaining, supra note 53 , at 32-35.

${ }^{55}$ See Forms and Limits, supra note $\mathrm{r}$, at 395 ; Adjudication and the Rule of Law, sucpra note 53 , at 3 .

${ }^{58}$ Fuller, Irrigation and Tyranny, I7 STAN. L. REv. ז02 I (I965).

${ }^{57}$ Fuller, Mediation - Its Forms and Functions, 44 S. CAL. L. Rev. 305, 334-37 (I97x).

${ }^{58}$ Forms and Limits, supra note $I$, at 395. 
preference and then march down the list in alternation, or ask a judge to do so. Rather, the parties' preferences are interactive in that their priorities will change as each choice is made. So, too, in assigning football players to positions the coach cannot simply select players in order of ability: the choice of one player at one position may influence the choice of another player at a different position. Similarly, the watermaster cannot judge each farmer's case separately, but must fit the cases together like a jigsaw puzzle, so that no single allocation can be made until all are made.

Fuller's treatment of the limits of adjudication raises several difficulties. To begin with, polycentricity seems to be related as much to the nature of the optimum solution as to the nature of the problem itself. Thus (as Fuller recognized), ${ }^{50}$ many problems can be converted from polycentric to nonpolycentric by changing the nature of the solution, if the parties are willing to undergo the costs such a conversion entails. For example, in the Timken case the paintings could simply have been sold and the proceeds divided, thereby allowing each museum to make art purchases on the market. Such a solution, however, would have been at the expense of undergoing significant transaction costs and failing to effectuate Timken's intent. More generally, many legal problems seem nonpolycentric only because the common law solves them by treating as "irrelevant" a number of circumstances and ramifications that might be considered perfectly relevant at other times or places.

A more important difficulty grows out of Fuller's virtually exclusive focus on polycentricity. It is beyond the scope of this essay to define the limits of adjudication in a comprehensive manner, but I would suggest that at a minimum there must be added to the test of polycentricity what might be called the problem of multiple criteria. Adjudication is an appropriate ordering process only when decision can be reached by determining rights through the application of an authoritative standard. Thus the watermaster and football cases are unsuitable for adjudication not only because they are polycentric, but also because they involve situations in which there are competing claimants for a given subject-matter, none of whom has a substantive right that can be determined by the application of an authoritative standard. In the watermaster case no farmer has a right to any given amount of water; in the football case no player has a right to any given position. At most, each farmer and each player has a right to have his claim fairly considered under appropriate criteria applied to all those who are similarly situated. True, many of those criteria can be identified. In the football case, for example, they 
include experience, desire, intelligence, condition, durability, discipline, team spirit, and various kinds of ability. But a list of criteria that is both exhaustive and exclusive would not be easy to assemble. What is more important, even if all relevant criteria could be listed, no criterion would be authoritative in the sense that it would trump other criteria, or even in the sense that it carried an objective weight in relation to others. One football coach may legitimately emphasize one kind of ability, a second another kind, and a third experience. One museum director may seek a balanced collection while another may emphasize developing a collection that is strong in certain areas.

If in these cases a single criterion could be made dispositive, it would be possible to determine rights by the application of that criterion and therefore by adjudication. The same might also be true if all criteria could be objectively weighted and choices were not interdependent. Often, however, the criteria cannot be reduced to one or objectively weighted, except by seriously impoverishing the solution. Where that is the case, and where the situation does not lend itself to a negotiated outcome, an optimum solution can normally be arrived at only by vesting a single decisionmaker with "managerial" authority - by which I mean authority not only to apply relevant criteria, but to determine how much weight each criterion is to receive and to change those weights as new objectives and criteria may require. In such cases the decisionmaker may not use improper criteria, and should apply the same criteria to all those similarly situated, but while he holds his position he can appropriately give to all proper criteria whatever weight he thinks appropriate. ${ }^{60}$

The problem of multiple criteria tends to be associated with the problem of polycentricity, but the two concepts are separate in theory and sometimes separate in practice. For example, choosing members of a college golf team may involve multiple criteria but not polycentricity, because golf is played on an individual basis and selection of the team therefore entails little or no interaction between choices. Similarly, a problem of multiple criteria would be involved if Timken had left to a nephew and a niece "in equal shares" a collection of valuable and cherished family heirlooms, no two of which fell into the same category (e.g., a clock, a chair, a bracelet). This problem would not, however be polycentric, because the choices are not interactive. Since no two heirlooms fall into the same category, each legatee could list the heirlooms in an order of preference that would not be affected by the choices actually made.

8o Cf. R. Dworkin, Taking Rights SeriousLy 3I-33 (x977) (discretion in the strong sense). 
Having these problems in mind, the following nonexclusive test might be suggested in place of polycentricity: Classical adjudication is an inappropriate process for solving problems whose optimal solution consists of a regime whose elements are discretionary in the sense that (i) interdependent interests must be manipulated to create the regime, thereby undermining the relevance of standards designed to assess competing claims of right, or (ii) the difficulty of ordering criteria in a preferential manner, or the presence of other severe uncertainties, frustrates creation of the regime through the formulation of stable decisional rules. ${ }^{01}$

It should be emphasized that the applicability of this test does not preclude assured participation. Fuller attempted to derive the polycentricity test from the Participation Thesis, on the ground that if polycentric tasks were assigned to adjudication it would be impossible to preserve the meaning of participation through proofs and argument. However, the fact that a problem is either polycentric or governed by multiple criteria is not inconsistent with this form of participation. For example, surely the museums in the Timken case would have been permitted to present proofs and argument if the allocation of paintings had to be made by the probate court; and surely farmers ought to have the right to present evidence and argument to the watermaster before he makes his decision. ${ }^{62}$ Even in the football case it would not be inconceivable to give players the right to have their say before the coach selected the starting team. The difficulty of utilizing adjudication to deal with such issues stems not from inability to assure participation through proofs and argument, but from the norm of strong responsiveness: it would be inconsistent to remit such issues to managerial authority (or negotiation), on the one hand, and to require the decision to proceed from and be congruent with the parties' proofs and arguments, on the other. If assured participation in such cases is deemed appropriate, it should therefore ordinarily take the form of the consultative process, in which strong responsiveness is not expected and the parties' right to make proofs and argument is fully consistent with a decisionmaker's managerial authority.

\section{III}

A question raised by the publication of Forms and Limits thirty years after it was written is the extent to which its analysis remains relevant in light of movement in the adjudicative process.

${ }^{61}$ For parallels to this test in Fuller's own work, see Collective Bargaining, supra note 53, at 31-32; Forms and Limits, supra note I, at 367-70, 404.

${ }^{62}$ See Fuller, supra note 56 , at 336 . 
This question can be put in its sharpest form by juxtaposing Fuller's analysis with that of Abram Chayes in The Role of the Judge in Public Law Litigation. ${ }^{63}$ Chayes begins by setting out the elements of a traditional model. This model conceives of adjudication as bipolar, retrospective, self-contained, and party initiated and controlled. Further, it takes as a central premise that right and remedy are interdependent. Pointing to schooldesegregation, employment-discrimination, and inmates' rights cases, Chayes argues that a new type of litigation has emerged, which he calls the public law model. Here, the characteristics of the traditional model are reversed. The party structure is amorphous rather than bipolar, the inquiry is predictive rather than retrospective, the process is heavily shaped by the judge, and perhaps most important, relief is often neither confined in its impact to the immediate parties nor conceived as compensation for past wrongs in a form logically derived from substantive liability. Instead, relief takes the shape of a forward-looking decree that embodies a complex affirmative regime "fashioned ad hoc on flexible and broadly remedial lines." 64 In adjusting that regime to take account of competing interests, "right and remedy [become] pretty thoroughly disconnected." ${ }^{65}$ Furthermore, relief is often not imposed by the court but negotiated by the parties, and frequently the decree does not terminate judicial involvement but instead requires the court's continuing participation.

How does the analysis in Forms and Limits hold up when applied to this new model of litigation? To answer this question, it is necessary to distinguish (i) between liability and remedy, and (ii) between the concept of participation and the limits of adjudication. Although the traditional model may have been the backdrop of Forms and Limits, no element of the public law model is inconsistent with Fuller's concept of participation. Indeed, the public law model fully reflects the working out of that concept to its logical conclusion, by according formal recognition (through expansion of the doctrine of intervention and recognition of groups as proper plaintiffs) to the fact that "those affected" by the results of adjudication, both directly and indirectly, may be a much larger group than the moving disputants. But just because a public law decision affects so wide a group, the court

${ }^{83}$ Chayes, The Role of the Judge in Public Law Litigation, 89 Harv. L. Rev. I28I (I976). See also Developments in the Law-Section 1983 and Federalism, 90 HARV. L. REV. Ir33, I227-50 (I977).

${ }^{64}$ Chayes, supra note 63 . Chayes notes a number of other areas in which the public law model is applicable, including bankruptcy and reorganizations, union governance, housing discrimination, and environmental management. Id. at I284.

${ }^{65} \mathrm{Id}$. at $\mathrm{x} 293$. 
may believe it inappropriate, in determining liability, to base its decision on the issues raised by those few members of the group who happen to be in the courtroom. In such cases, therefore, the judge may subordinate the norm of settling the dispute that has been put to him, on the basis of the issues put to him, in favor of the function of making rules that are responsive to public needs. Accordingly, the decisionmaking process as to liability in a public law case may edge toward a consultative form.

The difficulties on the remedy side are also severe. Because such remedies typically involve the adjustment of many competing institutional and human interests, the decree in a public law case often looks very much like a discretionary regime addressing a problem governed by multiple and polycentric criteria. In this respect the formulation of such a decree resembles the problem of dividing the paintings in Timken, and it is therefore instructive to spell out some further implications of that case. Timken rests on a different footing than the watermaster and football cases in two respects. On the one hand, Timken is inappropriate for adjudication not simply because of the problems of polycentricity and multiple criteria, but also because an optimum division of the paintings would turn almost entirely upon the parties' utilities; the parties are likely to have different value schedules, and only the parties know their own value schedules. Thus the optimum solution in Timken would be achieved not by the process of managerial direction, but by the process of negotiation. On the other hand, the claimants in Timken do have substantive rights in the subject matter. True, neither party has a right to any given painting, but it follows from an authoritative standard laid down by probate law (duly executed wills are enforceable) that each museum has a right to half of the paintings. If, therefore, the parties cannot reach a negotiated solution, each has a right to have the paintings allocated by the adjudicative process - whether or not that process is appropriate. Furthermore, despite the inappropriateness of adjudication the court serves an extremely important function in this type of case. While the optimum result would be reached by the process of negotiation, the right of each museum to resort to adjudication is the element which assures that negotiation will be conducted, and conducted in good faith.

In a public law case too, at least one party will have established a substantive right before the remedy stage is reached. (It may be that, unlike Timken, no more than one party will have established such a right. However, this will not necessarily be the case. More than one class of plaintiffs may have prevailed, and their interests may conflict. In addition, the right of the plaintiff in such cases often cannot be driven home to its ultimate 
conclusion without impinging upon the interests of third parties such as fellow workers in employment discrimination cases and fellow students in school desegregation cases.) Furthermore, once the remedy stage is reached the court has determined that some applicable legal standard has been violated. While other criteria may be relevant in framing the decree, that legal standard must assume pride of place. Although details of the decree - what kind of preferences should be given and for how long to minority employees, what percentage of minority and nonminority students will constitute a racially balanced school - may not follow simply from articulating and drawing out the standard's implications, the standard will nevertheless point out "the general direction to be pursued and a few salient landmarks to be sought out or avoided." 68 Thus the process of shaping a decree in a public law case stands midway between the formulation of a discretionary regime and the determination of traditional adjudicative issues.

All this being so, it might be expected that the court's role in formulating such decrees would ideally be like the court's role in Timken - a role not of shaping the regime in the first instance, but of standing ready to step in and thereby assuring that the regime is shaped by the parties. And, indeed, this is precisely what Chayes suggests.

How then is the relief formulated?

The reports provide little guidance on this question. Let me nonetheless suggest a prototype that $I$ think finds some support in the available materials. The court will ask the parties to agree on an order or it will ask one party to prepare a draft. In the first case, a negotiation is stipulated. In the second, the dynamic leads almost inevitably in that direction. The draftsman understands that his proposed decree will be subject to comment and objection by the other side and that it must be approved by the court. $\mathrm{He}$ is therefore likely to submit it to his opponents in advance to see whether differences cannot be resolved. Even if the court itself should prepare the initial draft of the order, some form of negotiation will almost inevitably ensue upon submission of the draft to the parties for comment.

If the parties are simply in disagreement, it seems plausible to suppose that the judge's choice among proposals advanced by the quondam negotiators will be governed by his appraisal of their good faith in seeking a way to implement the constitutional or statutory command as he has construed it. The interest in a decree that will be voluntarily obeyed can be promoted by enforcing a regime of good faith bargaining among the parties. ${ }^{67}$

${ }^{67} \mathrm{Id}$. at I298-300 (footnotes omitted). 
The problem can be viewed from a slightly different perspective. In many public law cases an optimum form of ordering would be good faith negotiation based on the relevant legal principles. ${ }^{68}$ That form of ordering could have occurred prior to the determination of liability, but did not - perhaps because one of the parties had a drastically incorrect premise concerning its legal obligations. The decision on liability having corrected that premise, the parties may now negotiate as they should have in the first instance. As in Timken, determination of the precise regime that will order the parties' relationship may be an inappropriate task for adjudication, but the major function of the court at the decree stage is not so much to adjudicate as to induce good faith negotiation by standing ready to do so.

This posture, however, is not without its dangers. As Fuller suggested in another context, under such circumstances the adjudicator may be tempted to step into the negotiation as a mediator, and the combination of the two roles is "a tricky business." ${ }^{69}$ Even if this temptation is resisted, another problem may arise. Commenting on a provision in a long term supply contract that if the parties could not agree on price it should be determined by arbitration, Fuller noted:

In practice the arbitration clause . . . is included in the fervent hope that it will not have to be used; it is intended as a spur toward a negotiated agreement. On the other hand, the substance of the negotiations can scarcely escape being influenced by the parties' conceptions of what a resort to arbitration would probably produce. . . . [But] if the arbitrator's powers are invoked he may try to decide the case by asking how the negotiations would have come out had the parties been more reasonable toward each other. Thus, each side of the arrangement - that is, the arbitrator, on one side, the parties on the other - is likely to borrow its standards from the other - something generally undesirable and working against a fully effective use of either form of order, contract or adjudication. ${ }^{70}$

The underlying message of Forms and Limits cannot be lightly disregarded: adjudication has a moral force, and this force is in major part a function of those elements that distinguish adjudication from all other forms of ordering. In the long run, the cost of departing from those elements may be a forfeiture of the moral force of the judicial role. ${ }^{71}$

${ }^{68}$ See Eisenberg, Private Ordering Through Negotiation: Dispute-Settlement and Rulemaking, 89 HARv. L. REv. 637 (I976).

${ }^{69}$ Collective Bargaining, supra note 53 , at 39 .

${ }^{70}$ Forms and Limits, supra note I, at 407.

${ }^{71}$ Collective Bargaining, supra note 53 , at 39. 
The development of public law litigation challenges in an important way Fuller's view of the limits of litigation. Chayes' article marks the beginning of an effort to rationalize this development, and suggests at least a cautious optimism. The philosophy expressed in Forms and Limits remains the best worked out and most persuasive perspective from which to criticize this development. It can hardly be said that this philosophy has triumphed, but it is of immediate relevance at the cutting edge of adjudication. The very definition of that process is now in question. Whether expansion of the public law model will undermine the moral force of adjudication, whether Fuller's view will be shown to have been too confining, or whether the publication of Forms and Limits will itself influence the lines of future development in the public law area, remains to be seen.

\section{CONCLUSION}

For the purpose of bringing a form of social ordering into focus, analyzing its characteristics, and exploring what problems that form is best suited to solve, it is often necessary to emphasize the discontinuities among ordering processes. As living institutions, however, the forms of social ordering are characterized by important continuities, including common elements that take different shades of meaning according to the process involved. Thus responsiveness runs on a continuum from a relatively restrictive and constraining norm, as in classical adjudication, to the more diffuse norm of serving the public's needs that is a general aspiration of democratic institutions. Similarly, participation runs on a continuum from cases in which all persons who are directly affected by a decision have a right to participate in its formulation, as in negotiation, to cases in which participation may occur but is not institutionally defined and assured, as in legislation. But while the shade of meaning given to participation and responsiveness helps define each ordering process, that meaning may also vary within a given process, depending partly on the goals to be served in the case at hand. In general, a restrictive form of responsiveness and a strong form of participation are suitable in classical adjudication; more diffuse forms of responsiveness and participation are suitable in legislative or managerial contexts. By analogy, an adjudicator who emphasizes dispute settlement is likely to take a more restrictive view of his obligation to be strongly responsive to the parties' arguments than one who perceives his main concern as dealing with public issues and perceives parties as interest group representatives. A proper appreciation of the forms and limits of adjudication turns 
in large part on determining the point at which responsiveness and participation either become so diffuse that the process loses its internal morality or, from a different perspective the process becomes unequal to the task because the nature of the problem demands more diffuse forms of responsiveness and participation than adjudication can legitimately provide. 